\title{
The Maritime Labour Convention, 2006-reflections on challenges for flag State implementation
}

\author{
Moira L. McConnell
}

Received: 25 July 2011 / Accepted: 2 September 2011 / Published online: 27 September 2011

(C) World Maritime University 2011

\begin{abstract}
This paper begins by providing a brief overview of the International Labour Organization's Maritime Labour Convention, 2006 (MLC, 2006), noting that this Convention, often called the "Seafarers' bill of rights", seeks to achieve both social and labour rights ("decent work") for seafarers and fair competition (achieving a level-playing field) for shipowners. It has been described as the "fourth pillar" of the international maritime regulatory regime complementing the major International Maritime Organization conventions. The paper provides a brief update on international efforts to achieve the $30 / 33$ formula needed to bring the Convention into force [at present, the tonnage element, 33\% has been achieved already with coverage now at $54 \%$ of the world fleet (by gross tonnage), with 18 ratifications]. It then explores challenges faced by flag States in connection with capacity to implement the ship inspection and certification system under the MLC, 2006 and other difficulties with respect to legal implementation by the flag States. The paper also comments on some challenges in connection with port State, coastal State and labour-supplying State responsibilities. The paper points out that the MLC, 2006 is a comprehensive code that covers diverse issues and a wider range of both ships and seafarers than previous conventions. It often requires interdepartmental cooperation to implement its requirements at the national level. The paper concludes that, despite the slower pace of ratification in some regions, largely because of the recent economic and other crises, it appears that many actors in the maritime sector are already actively engaged in MLC, 2006 implementation, often ahead of governments. The question is not "if" but "when" the formula will be achieved to allow the MLC, 2006 to enter into force.
\end{abstract}

Keywords Human element · ILO • Martime Labour Convention, 2006 · Seafarers' working and living conditions · Ship inspection and certification

M. L. McConnell $(\bowtie)$

Marine \& Environmental Law Institute (MELAW), Dalhousie University, Schulich School of Law, Halifax, Nova Scotia, Canada

e-mail: Moira.Mcconnell@dal.ca 


\section{Introduction ${ }^{1}$}

The Maritime Labour Convention, 2006 (MLC, 2006) ${ }^{2}$ was adopted ${ }^{3}$ on 23 February 2006 at the 10th maritime session and 94th session of the International Labour Conference (ILC) of the International Labour Organization (ILO). ${ }^{4}$ The Convention, comprising over 100 pages of text, elaborates a comprehensive code setting out rights and responsibilities as well as more technical minimum standards for working and living conditions for a diverse range of ocean workers (inclusively called "seafarers"5). Consistent with the complexities of the earliest of the globalized

\footnotetext{
${ }^{1}$ The introductory parts of this paper draw upon prior publication. In particular, see a guest editorial, McConnell 2011, see also McConnell et al. 2011 and McConnell 2009.

${ }^{2}$ See the ILO's MLC, 2006 website which contains the Convention and other key resources: $<$ http://www. ilo.org/global/standards/maritime-labour-convention/lang-en/index.htm.>.

${ }^{3}$ Remarkably given its scope and length, the Convention was adopted with essentially unanimous agreement as there was no vote against it by any of the tripartite (see infra note 4) delegations from 106 countries. The government representatives of two ILO members, Venezuela and Lebanon, abstained for reasons placed on the record that were unrelated to the substance of the Convention. Venezuela abstained for reasons relating to its views on the reference in the Preamble of the MLC, 2006 to the 1982 United Nations Convention on the Law of the Sea (see infra note 7), but placed on record its support for the substance of the Convention. Lebanon also abstained and placed on record its support for the convention but felt it could not vote in favour because of its lack of financial capacity to implement conventions (see Ninth Sitting 2006).

${ }^{4}$ The ILO, a specialized agency of the United Nations (UN), was established in 1919, predating the UN. In 1946, the ILO became the first specialized agency after the UN was established. The ILO describes it itself as
}

... devoted to advancing opportunities for women and men to obtain decent and productive work in conditions of freedom, equity, security and human dignity. Its main aims are to promote rights at work, encourage decent employment opportunities, enhance social protection and strengthen dialogue in handling work-related issues. In promoting social justice and internationally recognized human and labour rights, the organization continues to pursue its founding mission that labour peace is essential to prosperity.

It differs in several important respects from other UN organizations, the most fundamental of is its tripartite nature. Under the ILO's Constitution, the "State" is conceived of as a tripartite entity comprising workers, employers and government. Although only governments can ratify conventions (and be held accountable in international law), all three vote on the adoption of international legal instruments at the ILO (using a weighted voting formula). There are 183 members (States) of the ILO (as of August 2011). The ILC meets annually to discuss international labour standards as well as broader social and labour policies and programmes of the ILO. At periodic intervals (ten to date), the ILO holds an extra ILC session devoted to addressing issues in the maritime sector. The ILO maintains its headquarters (the International Labour Office) in Geneva, Switzerland. For more information see McConnell et al. 2011, supra note 1, Part I, and more generally the ILO website: "Who we are" available at $<$ http://www.ilo.org/global/aboutthe-ilo/who-we-are/lang-en/index.htm>.

${ }^{5}$ MLC, 2006, Article II, paragraph 1 (f) "seafarer means any person who is employed or engaged or works in any capacity on board a ship, to which the Convention applies." A ship is also inclusively defined in Art. II, paragraph 1 (i) as "ship means a ship other than one which navigates exclusively in inland waters or waters within, or closely adjacent to, sheltered waters or areas where port regulations apply." There are very few exclusions for categories of ships and, unlike IMO conventions, there is no minimum tonnage for application of the Convention. The exclusions under Article II, paragraph 4 are: "Except as expressly provided otherwise, this Convention applies to all ships, whether publicly or privately owned, ordinarily engaged in commercial activities, other than ships engaged in fishing or in similar pursuits and ships of traditional build such as dhows and junks. This Convention does not apply to warships or naval auxiliaries." 
economic sectors, ${ }^{6}$ the Convention establishes a system based on responsibilities for countries as flag States, port States, and, to a lesser degree, coastal States. It also introduces a new "face" for State responsibility, under the framework of international law of the sea, the State with labour-supplying responsibilities. Sometimes described as the "Seafarers' bill of rights" , the MLC, 2006 is an instrument that seeks to achieve both human rights goals and economic goals. Social and labour rights ("decent work"9 for seafarers) are interwoven with more economic fair competition considerations

\footnotetext{
${ }^{6}$ We cannot ignore the fact, as noted by Doumbia-Henry et al. (2006), that:

The maritime sector, in particular international shipping, is one of the earliest and most internationalized, with the beneficial ownership of ships often based in one State even though the ships operate under the jurisdiction of yet other States (flag States) and the seafarers on board are drawn from numerous States. The jurisdictional problems this can create and the issue of ensuring flag State responsibility have been topics of concern for this sector since the 1950s.
}

${ }^{7}$ Under the law of the sea regime as codified in the 1982 United Nations Convention on the Law of the Sea [UN Doc. A/Conf. 62/122, 21 I.L.M. 161 (entered into force on 16 November 1994), available at http://www.un.org/depts/los/convention_agreements/texts/unclos/closindx.htm] a State's possible interests and legal responsibilities are generally conceptualized as three roles or "faces": flag State, port State and coastal State. Most, but not all, States with a maritime interest have varying degrees of all three interests.

${ }^{8}$ This idea is expressed in the MLC, 2006, Article IV which provides inter alia, that:

Seafarers' employment and social rights

1. Every seafarer has the right to a safe and secure workplace that complies with safety standards.

2. Every seafarer has a right to fair terms of employment.

3. Every seafarer has a right to decent working and living conditions on board ship.

4. Every seafarer has a right to health protection, medical care, welfare measures and other forms of social protection.

See also, most recently IFLOS 2011

${ }^{9}$ The term "decent work" encapsulates the contemporary agenda of the ILO:

The Decent Work concept was formulated by the ILO's constituents_-governments and employers' and workers' organizations - as a means to identify the Organization's major priorities. It is based on the understanding that work is a source of personal dignity, family stability, peace in the community, democracies that deliver for people, and economic growth that expands opportunities for productive jobs and enterprise development.

Decent Work reflects priorities on the social, economic and political agenda of countries and the international system. In a relatively short time, this concept has forged an international consensus among governments, employers, workers and civil society that productive employment and Decent Work are key elements to achieving a fair globalization, reducing poverty and achieving equitable, inclusive, and sustainable development.

See ILO, "Decent work agenda" available at <http://www.ilo.org/global/about-the-ilo/decent-workagenda/lang-en/index.htm>. 
(achieving a level-playing field ${ }^{10}$ for shipowners). It has been described as the "fourth pillar" of the international maritime regulatory regime complementing the major International Maritime Organization (IMO) conventions, the International Convention for the Safety of Life at Sea, 1974 (SOLAS), the International Convention for the Prevention of Pollution from Ships, 73/78 (MARPOL) and the International Convention on Standards of Training, Certification and Watchkeeping for Seafarers, 1978 (STCW), all of which are intended to ensure the safety, security of shipping and the protection of marine environment from ship source pollution. ${ }^{11}$

As an ILO legal instrument, the MLC, 2006 brings together and modernizes in some areas (for example onboard accommodation and occupational safety and health) the majority of the ILO's maritime legal instruments adopted since 1920 (41 conventions ${ }^{12}$ and the related recommendations - 70 instruments in total). The 37 maritime labour Conventions that are consolidated ${ }^{13}$ will be gradually phased out as States that are now party to these Conventions ratify the MLC, 2006.

The Convention sets out minimum requirements for seafarers to work on a ship (e.g. minimum age, medical fitness, training, regulated seafarer recruitment and placement

\footnotetext{
10 "Level-playing field" is a phrase used to refer to the idea of fairness in competition in the sense that each player in the particular "game"/trade operates under the same basic rules or conditions. In the context of maritime labour issues, a concern has been that with the increasing regulation of environmental and safety and security matters on ships to eliminate substandard ship and operators, labour costs remain one of the areas where operating costs maybe substantially reduced. Thus, "quality shipowners" who would provide decent working conditions risk being undercut by operators that are not required to provide these conditions and therefore can be seen as competing unfairly. The MLC, 2006 aims, through various provisions, such as Article V, paragraph 7 ("no more favourable treatment" of ships of non-ratifying countries in connection with port State control), to address the unfair competition resulting from shipowners and flag States condoning or failing to regulate poor or substandard (below international norms) working conditions. This view of fairness is, of course, one that can be debated, especially in the context of developing economies, some of which may perceive this concern as related to the increasing competitiveness of workers based in those countries, relative to more costly workers based in countries with a developed economy. The outcome of this kind of regulatory undercutting between countries is sometimes described as a "race to the bottom". For more discussion of these ideas and global labour market for seafarers, see Wu and Sampson 2005 or Lillie 2006.

${ }^{11}$ Speech to the ILC by Mr. E. Mitropoulos, Secretary-General, International Maritime Organization, 94th (Maritime) Session, ILC, February 20, 2006, Fourth Sitting, Provisional Record 10, p. 2 International Convention for the Safety of Life at Sea, 1974, as amended; International Convention on Standards of Training, Certification and Watchkeeping for Seafarers, 1978, as amended; International Convention for the Prevention of Pollution from Ships, 73/78. The MLC, 2006 was specifically designed to become the "the fourth pillar" of the international maritime regulatory regime, complementing and completing the approach established in these core IMO conventions. This builds on the increasing appreciation of the key role of the "human element" in ensuring ship safety and security and preventing pollution. However, the relationship with the IMO conventions goes beyond this complementarity. The MLC, 2006 reflects a conscious decision to mainstream labour standard and compliance and enforcement practices within the existing maritime regulatory regime and put labour and social standards on the same level as these other issues. See: "Two draft papers on enforcement and simplified amendment; Considerations for provisions on inspection and control in a consolidated maritime labour Convention (draft I); Simplified amendment procedure for the proposed new maritime labour Convention (draft II), Tripartite Subgroup of the High-Level Tripartite Working Group on Maritime Labour Standards (First Meeting), Geneva, 2002, ILO Doc. No. STWGMLS 2002/1, available at <http://www.ilo.org/public/english/ dialogue/sector/techmeet/stwgmls02/stwgmls-1.pdf $>$

${ }^{12}$ The ILO has other maritime labour conventions setting labour and social standards for fishing, dock work and inland navigation.

${ }^{13}$ MLC, 2006, Article X. Four Conventions were not included, the two conventions on seafarers' identity documents (Nos. 108 and 185), a convention on seafarers pensions (No. 71) and one, outdated convention on trimmers and stokers (No. 15).
} 
services) and conditions of employment, including important matters such as a contract of employment [seafarers' employment agreements (SEA) ${ }^{14}$ ], minimum hours of work or rest, wages, leave, repatriation and other matters. It also contains provisions dealing with standards for accommodation ${ }^{15}$ and recreational facilities, food and catering on board ship, as well as addressing medical care on board and ashore including shipowners' liability in that context, health and safety protection and accident prevention, access to seafarer welfare centres and social security protection.

It provides an important example of inter-organization learning as it builds upon and, arguably, develops the best practices for effective compliance and enforcement that have evolved under the international regulatory regime in connection with the IMO conventions. ${ }^{16}$ The MLC, 2006 contains, in Title 5, obligations to establish a compliance and enforcement system based on regular inspections and, in the case of ships 500GT engaged in international voyages or 500GT operating between ports in a country other than the flag State, mandatory certification of labour and social conditions for seafarers, carried out by the competent authority in the flag States or recognized organizations (ROs) on their behalf. ${ }^{17}$ This is complemented by port State inspection [port State control (PSC)] and responsibilities for labour-supplying issues. Aside from labour-supplying responsibilities, these generally follow the existing IMO practices, with a few small differences. However, the Convention also contains aspects reflecting ILO practices and its emphasis on tripartism with onboard and onshore seafarer complaint procedures and linkages to the wellestablished ILO supervisory system which formally examines legal implementation at the State level. In order to encourage fair competition, the Convention requires port States to ensure that ships of non-ratifying States receive "no more favourable treatment" during PSC than that given to ships of ratifying States. ${ }^{18}$ The Convention expressly seeks to attract widespread ratification through a mix of firmness on rights combined with flexibility on implementation supported by a tripartite approach to implementation at the national level. Typically, for an ILO convention, it allows implementation in laws and/or regulations or collective agreements or other measures, ${ }^{19}$ thus emphasizing the important role of the national social partners, the workers and employers, in implementing international obligations.

\footnotetext{
${ }^{14}$ It includes articles of agreement and can incorporate by reference a collective bargaining agreement.

15 There is a provision that deals with the difficult issues of construction and equipment on existing ships (MLC, 2006, Regulation 3.1, paragraph 2).

${ }^{16}$ Although now primarily concerned with the IMO Conventions, it is interesting to note that the Paris PSC Memorandum of Understanding (MOU) was in fact developed in response to an ILO Convention, the Merchant Shipping (Minimum Standards) Convention, 1976 (No. 147).

${ }^{17}$ It appears to go beyond the numerous IMO instruments (IMO Resolution A.739(18) Guidelines for the Authorization of Organizations Acting on Behalf of Administrations, and its predecessor IMO Resolution A.739(18) Guidelines for the Authorization of Organizations Acting on Behalf of the Administration, adopted 4 November 1993, and the Code for the Implementation of Mandatory IMO Instruments, 2007, IMO Doc. No. A. 25/Res.996, 15 January 2008 (paragraph 18) as amended by "2009 Consolidated Version of the Code for the Implementation of Mandatory IMO Instruments, 2007" containing amendments to the Code for the Implementation of Mandatory IMO Instruments, 2007, adopted by resolution A.1019(26) in that the MLC, 2006 contains at the level of an international convention, binding obligations regarding authorization and oversight of any authorized ROs by the flag State (see: MLC, 2006, Regulation 5.1.2 and Standard A5.1.2).

${ }^{18}$ MLC, 2006, Article V, paragraph 7.

${ }^{19}$ MLC, 2006, Article IV, paragraph 5
} 
It is important to keep in mind the point mentioned above: the MLC, 2006 is intended to establish decent work for seafarers and a level-playing field for shipowners. In that equation, despite the clear attempts to provide national flexibility, these two are inseparable and are predicated on the idea of some uniformity in implementation and related inspections. This is also central to the idea, new for an ILO convention, of certifying labour standards in the maritime sector.

The key features of the MLC, 2006, which as discussed below also create challenges for implementation, can be summarized as:

- Comprehensive approach to the issues covered,

- Comprehensive approach to coverage of seafarers and ships (no tonnage limit),

- A new system to mainstream labour standards within the international maritime regulatory system in order to achieve effective enforcement and compliance-a certification system for conditions of "decent work" (some tonnage/voyage parameters on certification), and

- Specific areas for national flexibility based on national social (tripartite) dialogue.

\section{The current status of MLC, 2006 ratification and implementation}

This year-2011-is an important milestone year for the MLC, 2006. As mentioned earlier, February marked the fifth anniversary of the adoption of the Convention by the 94th ILC, at its 10th maritime session since 1920. This year was also the tenth anniversary of the famous "Geneva Accord", an agreement that was reached in 2001 by the international representatives of the seafarers and shipowners on the ILO's Joint Maritime Commission. This Accord called for a legal instrument that would more effectively address the needs of the seafarers and shipowners in the earliest of the globalized industries and provided the impetus ${ }^{20}$ for the five years of intensive international tripartite meetings leading to the adoption of the MLC, 2006.

As noted above, despite what was, essentially, unanimous adoption in 2006, the Convention has not yet achieved the formula for entry into force- 12 months after ratification by 30 Members (States that are members of the ILO) with a total share in the world gross tonnage of ships of at least 33 per cent (MLC, 2006, Article VIII). Although most of the major flag States have ratified the Convention, with ratifications currently covering seafarers on more than $54 \%$ of the world fleet, as of August 2011, the Convention has been ratified by only 18 countries. ${ }^{21}$ This means that 12 more ratifications are needed meet the 30/33 formula in 2011, with actual entry into force of the Convention 12 months later. As noted ${ }^{22}$ by Cleopatra Doumbia-Henry, Director of the ILO's International Standards Department,

\footnotetext{
$\overline{{ }^{20} \text { Recall also in } 2000 \text { the report }}$ of the International Commission on Shipping 2000.

${ }^{21}$ In order of ratification they are: Liberia, Marshall Islands, Bahamas, Panama, Norway, Bosnia and Herzegovina, Spain, Croatia, Bulgaria, Canada, St Vincent and the Grenadines, Switzerland, Gabon, Benin, Singapore, Denmark, Antigua and Barbuda, and Latvia.

22 "Overview of the MLC, 2006, status of implementation and emerging issues" opening presentation to the "Asia-Pacific, a Regional Dialogue on the Maritime Labour Convention" organized by the Australian Maritime Safety Authority 3-6 May 2011 Cairns, Queensland, Australia.
} 
...[a]t the time the Convention was adopted it was thought it would take about 5 years to achieve the challenging formula which is intentionally demanding because of the importance of ensuring that the MLC, 2006 is not a "paper tiger" but an instrument that results in real change: decent work for seafarers and a level playing-field for shipowners.

Clearly, it is an ambitious Convention that aims for as close to universal ratification as possible.

It had been expected, with the decision by the European Union (EU) in 2007 regarding ratification by its members by the end of December 2010 and the agreement between the social partners in the EU, an agreement that will become a directive once the convention into force, ${ }^{23}$ that the other requirement, ratification by at least 30 Members would be achieved by December 2010. This date has now passed; however, the overall five-year goal may still be possible, as there has been significant progress in other countries, particularly in parts of Europe, Asia, Southeast Asia and the Pacific region. Many countries in the Caribbean are moving forward quickly, as well as several countries in Africa and Asia. ${ }^{24}$

Not surprisingly, the global economic destabilization combined with political and other difficulties in some countries and regions, as well as major environmental disasters has had a serious impact on national legislative agendas. These are all certainly what could be described as the more unpredictable exogenic factors that pose a challenge to governmental efforts, for all States including flag States, to move forward on ratification and implementation.

\section{Challenges for (flag State) implementation}

\subsection{A brief note on other than flag State obligations}

Although the focus of this paper is flag State implementation, it is important to keep in mind the fact that the Convention also contains important obligations for countries with

\footnotetext{
${ }^{23}$ The Council adopted a Decision on 7 July 2007 authorizing member States to ratify the ILO's MLC, 2006 in the interests of the European Community, preferably before 31 December 2010 (see EU Official Journal: L 161/ 63, 22 June 2007). On 19 May 2008, the EU social partners representing management and labour in the maritime transport sector (European Community Shipowners' Associations and the European Transport Workers' Federation) entered into the agreement on the MLC, 2006 and requested the European Commission to propose a Council Directive giving effect to their agreement and its Annex A under EU law, in accordance with article 139 of the treaty. A Directive was adopted in February 2009. See "Council Directive 2009/13/EC of 16 February 2009 implementing the agreement concluded by the European Community Shipowners' Association and the European Transport Workers' Federation on the Maritime Labour Convention, 2006 and amending Directive 1999/63/EC'. It will enter into force at the same time as the MLC, 2006.

${ }^{24}$ An online ILO news release, dated 9 May 2001, "Asia-Pacific towards the ratification of the MLC, 2006 MLC Asia-Pacific meeting in Cairns, Australia (3-6 May 2011)" reported that:
}

The ratification by a number of countries, including Antigua, Latvia and Poland appear imminent. Others, including India, have announced their intention to ratify within the next 6 months. During the Asian regional dialogue, the indications suggest that at least nine countries in the region could be in a position to ratify the MLC, 2006 before the end of 2011.

Available at $<$ http://www.ilo.org/global/standards/maritime-labour-convention/WCMS_155179/langen/index.htm>. 
labour-supplying responsibilities as well as coastal and/or port State responsibilities. These also provide significant challenges for governments - particularly those related to the regulation of private seafarers' recruitment and placement services (if any) that operate in a country and the, always complex, issue of providing social security for seafarers "ordinarily resident" in the country. Although both of these matters have some elements of flag State responsibility related to the verification of the situation during ship inspections, the regulatory responsibilities under the MLC, 2006 are not primarily directed to flag States. In the first case, responsibility rests with the State in which the service is located. In the second, it is the State in which the seafarer is "ordinarily resident" (unless flag State's social security system covers foreign seafarers on ships under its flag). There are also important obligations relating to adopting policies to promote employment opportunities, again a labour-supplying responsibility. Other obligations, which could be considered as coastal or port State concerns, such as encouraging the establishment of seafarer welfare centres and the provision of access to shore-based onshore medical advice and services to passing ships and ships entering the territory are also important and possibly difficult for some countries. There are also, potentially, some implementation issues in connection with elements of port State responsibilities, particularly where the procedures under the MLC, 2006 vary somewhat from those that are well established under the various PSC Memorandum of Understandings (MOUs), e.g. the onshore seafarer complaint-handling procedures.

\subsection{Implementation challenges for flag States}

It is clear that the majority of the obligations under the MLC, 2006 are directed to States in their capacity as flag States. These challenges, which are endogenous to the Convention, overlap to some extent but for purposes of this paper are divided into two categories

\subsubsection{Challenges related to inspection system capacity}

The first, most obvious, issue is the capacity to implement and operate the ship inspection and certification system. As was the case with the introduction of the major IMO instruments, MARPOL or, more recently, the ISM Code or ISPS Code under SOLAS, and in connection with other IMO conventions, this change in the system will inevitably have some teething problems and generate uncertainty at all levels for a period of time. For flag States with a high level of registered tonnage, the need to inspect and certify, if required, a large number of ships will be a challenge. As noted above in Section 1 of this article, the MLC, 2006 is comprehensive. It applies to existing ships (except for the construction and equipment aspects of accommodation) and, although there is some flexibility with respect to ships less than $200 \mathrm{GT}$, it does not have a tonnage limit. Nor does it have broad exclusions ${ }^{25}$

\footnotetext{
${ }^{25}$ As noted above, supra note 5, other than ships that are not commercially operated or engaged in fishing or are of traditional build or warships or naval auxiliaries. The question of the limits envisaged by the terms "sheltered waters" and "closely adjacent to sheltered waters" was the subject of an ILO circular letter in July 2011 (on file with the author). It mentions variations in practice based on geography; however, the need to ensure good faith implementation of the Convention and the fact that it is clearly intended to cover seafarers working on domestic fleet is also noted.
} 
based on ships' voyages/trade. To a large extent, the problem of capacity to inspect and certify, at least for ships engaged in international voyages, may already be addressed through the services provided by the ROs which have moved forward rapidly to make sure that they have staff that are competent to inspect and certify ships for MLC, 2006 compliance. ${ }^{26}$ In that respect, there may be one difficulty in that there has been a concern about ensuring some degree of uniformity in the way that ROs are interpreting the Convention's requirements, particularly at the present "infancy" stage when many flag States are still developing the legal details of implementation. It should be noted that the MLC, 2006 differs from the IMO conventions because of its emphasis on national flexibility and the specifics of the documentation on board ship, particularly the requirement for a Declaration of Maritime Labour Compliance, Part I to be filled out by governments. ${ }^{27}$ For this reason, the need to ensure that national legal capacity is built is important, as some countries may have difficulty implementing the various requirements in the Convention that require both tripartite consultation and adoption of laws or regulations in order to guide the authorized ROs. Clearly, under the MLC, 2006, ROs will require instruction on national standards. This is part of the problem regarding the need to build national capacity to both carry out and oversee inspections.

To help achieve more harmony, if not uniformity, in connection with the ship inspection obligations, the ILO organized an international tripartite experts meeting in 2008 to adopt the Guidelines for Flag State Inspections Under the Maritime Labour Convention, $2006^{28}$ and the Guidelines for Port State Control Officers Carrying Out Inspections Under the Maritime Labour Convention, 2006 (Guidelines for PSCOS). ${ }^{29}$ These Guidelines are not binding but are intended as tripartite advice to flag States, in particular, about the system for inspection and what is should be checked in an inspection. The Paris PSC MOU guidance, which is nearly completed, is not exactly the same as these Guidelines but generally follows the ILO's MLC, 2006 Guidelines for PSCOs. ${ }^{30}$

\footnotetext{
${ }^{26}$ See for, e.g. American Bureau of Shipping, with various publications $<$ http://www.eagle.org/ eagleExternalPortalWEB/appmanager/absEagle/absEagleDesktop?_nfpb=true\&_pageLabel=abs_eagle_ portal_svcs_marine_certsrvcs_ilo_pagez

Or the work of Det Norske Veritas (DNV), an RO that has been certifying ships and recruitment and placement services for several years $<$ http://www.dnv.com/press_area/press_releases/2010/dnvawards.asp $>$.

${ }^{27}$ The MLC, 2006 Standard A5.2.3, paragraph 10 requires that:

The declaration of maritime labour compliance shall be attached to the maritime labour certificate. It shall have two parts:

(a) Part I shall be drawn up by the competent authority which shall: (i) identify the list of matters to be inspected in accordance with paragraph 1 of this Standard; (ii) identify the national requirements embodying the relevant provisions of this Convention by providing a reference to the relevant national legal provisions as well as, to the extent necessary, concise information on the main content of the national requirements; (iii) refer to ship-type specific requirements under national legislation; (iv) record any substantially equivalent provisions adopted pursuant to paragraph 3 of Article VI; and (v) clearly indicate any exemption granted by the competent authority as provided in Title $3 \ldots$

${ }^{28}$ See the ILO's MLC, 2006 website which contains the Convention and other key resources, including these Guidelines: <http://www.ilo.org/global/standards/maritime-labour-convention/lang-en/index.htm>. ${ }^{29}$ Ibid.

${ }^{30}$ In addition, in November 2011, the Tokyo PSC MOU will hold a seminar on the MLC, 2006 to train PSCOs under the Tokyo PSC MOU on the requirements.
} 
These Guidelines have been combined with other initiatives such as the Maritime Labour Academy, based at the ILO's International Training Centre in Italy, ${ }^{31}$ which is an essential element in the major effort by the ILO to develop training for maritime labour inspectors in order to ensure some degree of consistency in practice and understanding in all regions. The first course, a two-week residential course that was developed in 2009, was the "Train the Trainers maritime labour inspectors on the application of the Maritime Labour Convention, 2006". Since then, more than 200 MLC, 2006 trainers from all regions have graduated from these courses, with more courses planned for 2011 and 2012, including courses in partnership with the ITF for ITF inspectors ${ }^{32}$ and workshops and courses for ships' masters and other officers, the cruise ship sector ${ }^{33}$ and for national legal counsel/advisers. Numerous regional and national level courses delivered by the ILO or trainers who have taken the ILO course have also taken place in addition to many other industry or national activities. $^{34}$

Clearly, capacity to operationalize the MLC, 2006 inspection system is being developed by both public and private actors in the maritime sector. There have also been many industry reports of ships and seafarer recruitment and placement services already being inspected and certified, either on a trial basis or under voluntary certification, as well as initiatives to include MLC, 2006 compatible terms in various industry collective agreements and other tools such as courses and training offered by ROs and others.

But these inspection challenges for governments should not be overstated. It is important to keep in mind the fact that the MLC, 2006 builds upon obligations that have been in place for many countries since the adoption of the ILO Convention No. $147^{35}$ which was an early attempt at consolidation and also contained a form of port State scrutiny of working and living conditions on ships. It is now one of the Conventions included under many of the PSC MOUs. In fact, Convention No. 147 and the Labour Inspection (Seafarers) Convention, 1996 (No.178) ${ }^{36}$ form the basis of the current compliance and enforcement system in the MLC, 2006. In principle, this means that, for countries that have ratified those Conventions, the "upgrade" to

\footnotetext{
${ }^{31}$ See $<$ http://mlc-training.itcilo.org/training-courses $>$. The course was developed with the assistance of the Italian Government, the MCA of the United Kingdom, Sweden, Korea and the Singapore Maritime Officers Union (SMOU).

32 Three have already taken place involving more than 60 ITF inspectors drawn from all regions.

${ }^{33}$ Developed in cooperation with the Costa Cruises Group.

${ }^{34}$ AUSAID/AMC (in Tasmania) April-May 2010 for South Pacific inspectors); In November 2010, a (pilot) three-day regional inspector training workshop was organized by the ILO in cooperation with the Jamaican Maritime Administration and the Caribbean PSC MOU. That workshop was attended by 40 participants. As of August 2011, 210 people from all regions of the world were trained at this course. A survey carried out in February 2011 by the ITC had a very high level of response-88/176 (176 trained as of February). These 88 people reported that after their course they carried out activities on their return home resulting in a total of at least 2,893 more people being trained or exposed with respect to the MLC, 2006. A national level course also took place in the Philippines in July 2011. The ILO has planned a legal workshop in September 2011. This course will also review draft model legal provisions that have been developed by the ILO.

${ }^{35}$ Supra note 16, <http://www.ilo.org/ilolex/english/convdisp1.htm> It has been ratified by 56 States. There is also a Protocol that was adopted in 1996 adding to the list of conventions covered by the general obligations under C147. P147 has been ratified by 24 States.

$36<$ http://www.ilo.org/ilolex/english/convdisp1.htm> It has been ratified by 15 States.
} 
the MLC, 2006 while certainly a "plusher" system should not, in fact, require a major change in basic maritime labour inspection operations.

\subsubsection{Challenges relating to legal implementation (and ratification) by flag States}

The challenges related to legal implementation are perhaps more difficult and certainly, along with the exogenous factors noted above, constitute a large part of the explanation of the slower than expected pace of ratification. Many countries, for example Canada, Australia and Singapore, do not normally ratify international agreements until their legislation is in place, even though there is a clear 12 months (or longer if a country ratifies before the 30th ratification needed to bring the Convention into force) "grace period" after ratification before the Convention obligations enter into force, and are, therefore, binding on the ratifying country. There is then a further period before a country would have to report to the ILO supervisory system on its implementation.

One of the main difficulties for implementation is that the MLC, 2006 is both a labour convention and a maritime convention. Interaction with the ILO including implementation of labour conventions is usually a matter dealt with by the labour departments or ministries in each country. However, the compliance and enforcement approach in the MLC, 2006, including PSC and the possible use of ROs and the express alignment with IMO instruments, is intended to "mainstream" it within the current flag State inspection and the PSC MOU approaches under the wider maritime regime. For some countries, the question of which department should handle the implementation of the MLC, 2006 has been difficult as this is a labour matter, usually involving labour inspectors; however, the Convention is obviously predicated, from a systemic perspective, on implementation by the competent authority or authorities that are already working with ship inspection and certification and with PSC. On the other hand, many of the topics such as social security or occupational safety and health and the possibility of implementation through collective bargaining agreements are not within the usual practice or jurisdiction of most maritime administrations. ${ }^{37}$

While there are some countries where the labour department and labour inspectors will play a central role, in many countries, implementation has occurred through cooperative arrangements between the relevant departments. This is especially important since some topics may be matters on which the maritime administration cannot develop legislation. To use the example of Canada, the majority of the MLC, 2006 provisions are addressed in a regulation under the Canada Shipping Act, $2001,{ }^{38}$ a statute dealt with by Transport Canada. However, some elements dealing with maritime occupational safety and health (MOSH) and seafarers' accommodation on board ship are set out in a regulation under the Canada Labour Code, ${ }^{39}$ a

\footnotetext{
${ }^{37}$ In the late 1990s, Edgar Gold wrote about this issue in connection with national implementation of the law of the sea and the trend to what he described as "departmental chauvinism" Gold 1999.

$38<$ http://www.tc.gc.ca/eng/acts-regulations/acts-2001c26.htm> Marine Personnel Regulations, Part 3, $<$ http://laws-lois.justice.gc.ca/eng/regulations/SOR-2007-115/>

${ }^{39}$ Canada Labour Code, <http://laws-lois.justice.gc.ca/eng/acts/L-2/>

Maritime Occupational Health and Safety Regulations (SOR/2010-120)

$<$ http://laws-lois.justice.gc.ca/eng/regulations/SOR-2010-120/>
} 
statute under the purview of Human Resources and Skills Canada. These institutional and legal issues are complex to work out, particularly in countries where departments have not previously worked together to develop MOUs or other cooperative arrangements to address issues and legislation that straddles departmental boundaries. The MLC, 2006 requires an integrated approach in order to achieve implementation.

Aside from ship inspection questions, the comprehensive coverage under the Convention also provides a challenge because the subject matter may span more than these two departments or in some cases even levels of governments (e.g. in federations). For example, the provision of social security to seafarers "ordinarily resident" in the country or access to onshore medical services may require discussion between a number of departments or levels of government, in some cases. This means that other ministries, particularly where financial or border security matters may be involved, need also to understand and support the Convention. These are all matters that can be difficult and take time to negotiate.

As mentioned earlier, although the MLC, 2006 consolidates older ILO conventions, some dating back to 1920, it also updates and "modernizes" the requirements in a number of areas particularly in connection with MOSH. There are very few models for some requirements, e.g. MOSH regulations and risk assessments, or the form of financial security required of ships (in connection with repatriation) or shipowners (in connection with death or long-term disability) or recruitment and placement services (for a failure by the service or a shipowner to meet their respective obligations).

For some flag States that breadth of the Convention has also provided difficulties in connection with specific sectors, most notably the domestic fleet, commercial yacht owners and the cruise ship industry, where the accommodation on ships and other workplace practices have not easily meshed with the MLC, 2006 requirements, even for future build ships. ${ }^{40}$ The domestic voyage fleet, in particular, has not previously been the subject of international standards.

Another difficulty that has been encountered by some flag States relates to the exercise of the national flexibility that exists under the Convention. In most cases, this must be exercised in or after consultation with the seafarer and shipowners' organizations concerned. However, a number of countries either do not have these organizations or, if they do exist, may not represent the seafarers on the ships or the shipowners concerned. This problem was, however, foreseen. When the Convention enters into force, or at least achieves the entry into force formula, the ILO's Governing Body is expected to establish the Special Tripartite Committee (under Article XIII). This Committee, in addition to considering amendments and reviewing how the Convention is working, has a special role, under Article VII, whereby it can act as the relevant consultative organization for countries that do not yet have social partners. There is an obvious gap until the Committee is established. However, in 2010, at a meeting of the Preparatory MLC, 2006 Committee, the establishment of a transitional arrangement was not accepted. ${ }^{41}$ This means that this gap-filling role

\footnotetext{
${ }^{40}$ Unless flag States provide otherwise, some elements of the Convention under the Code - Standard A3.1 and Guideline B3.1 relating to construction and equipment do not apply to existing ships: See MLC, 2006, Regulation 3.1, paragraph 2.

${ }^{41}$ Final report, Preparatory Tripartite MLC, 2006 Committee, September 2010, IL0 Doc. No. PTMLC/ 2010/4, at Appendix, "Outcomes" at page 29 and see also paragraph 131. Available at: <http://www.ilo. org/wcmsp5/groups/public/@ed_norm/@normes/documents/meetingdocument/wcms_150401.pdf>
} 
will only be addressed after the Convention achieves the entry into force formula and the Committee is established.

Another major difficulty for some countries, particularly less developed economies, is the problem of capacity to undertake the legal drafting tasks involved in implementing the MLC, 2006. ${ }^{42}$ This problem is not unique to labour conventions, for example the IMO has prepared and delivered numerous model laws and workshops to assist with implementation of IMO conventions. However, this approach is relatively rare for the ILO, perhaps because of the importance placed on promoting social dialogue in national implementation. However, as result of requests for this form of technical cooperation, model national provisions are now being finalized. The ILO has also supported national legal gap analysis in over 40 countries to assist countries to move forward.

Nonetheless, as noted earlier, while flag States may have had some difficulties in many respects, the industry has moved ahead of government with some organizations developing collective agreements and seafarer employment agreements that are in line with the MLC, 2006. In some cases, ships have already been certified along with private seafarer recruitment and placement services.

At the level of the broader international maritime law regime, some elements of the MLC, 2006 have strongly influenced the text of the recent amendments that were adopted by the IMO for its STCW Convention (the Manila amendments). ${ }^{43}$ These amendments are expected to enter into force in early 2012. This means that, even before the MLC, 2006 comes into force, its requirements relating to medical examinations and certificates, minimum age and hours of rest and training will already be mandatory for seafarers covered by the STCW.

\section{Conclusion}

It is clear that there are some challenges for flag State implementation of the MLC, 2006; however, as also suggested above, these should not be overstated. In fact, the industry seems to be moving forward, perhaps because, like most major regulatory changes, it generates a new market for some services or technologies, irrespective of the rather slow pace of the mechanics of legal implementation and ratification. Even on the latter point, it seems clear that reaching the requisite 30/33 formula is now simply a question of precisely "when" rather than "if". When the Convention enters

\footnotetext{
$\overline{42}$ Based on advice received at these seminars and at a meeting of the Preparatory Tripartite MLC, 2006 committee in September 2010, as noted above supra note 34 model national legal provisions are now under development with a workshop planned for September 2011 at the Maritime Labour Academy, ILO ITC, Turin, Italy.

${ }^{43}$ The STCW amendments essentially replicate the ILO provisions on minimum hours of rest; however, they also contain one additional paragraph that provides some limited flexibility that is not present in the MLC, 2006. On the other hand, the MLC, 2006, in Standard A2.3, paragraph 13, appears to provide even greater flexibility if it takes the form of a provision in a collective agreement. The question of the relationship between these two provisions was raised at an ILO tripartite meeting in September 2010, see report, supra note 41, and was the subject of comment by the International Labour Office, see especially paragraph 127. The main point of the reply was that, since States had adopted both provisions, States would need to reconcile their respective obligations under both. There is no direct conflict between them, however, in principle, if a country was bound by both Conventions, then, the STCW flexibility would need to be exercised in the form of a collective bargaining agreement. The MLC, 2006 flexibility does not contain the same limitations found in the STCW amendment.
} 
into force, the very interesting experiment of certifying labour standards to achieve "decent work" and a "level-playing field" will also, perhaps, finally address long held concerns about the problem created by the lack of a "genuine link" 44 between ships and the flag States.

\section{References}

Doumbia-Henry C, Devlin D, McConnell ML (2006) The Maritime Labour Convention, 2006 consolidates seafarers' labour instruments vol. 10, Issue 23, ASIL Insight (e-publication)

Gold E (1999) From process to reality: adopting domestic legislation for the Implementation of the Law of the Sea Convention. In: Vidas D, Ostreng W (eds) Order for the oceans at the turn of the century. Friedtj of Nansen Institute, Norway, p 383

International Commission on Shipping (2000) Inquiry into ship safety, slavery and competition. ICONS, Australia

International Foundation for the Law of the Sea (IFLOS) (2011) Maritime talks 2011 ILO Maritime Labour Convention, 2006 - a 'Magna Carta' for seafarers? <http://www.iflos.org/en/events/maritime-talks/ maritime-talks-2011-ilo-maritime-labour-convention,-2006-a- $\% 27$ magna-carta\%27-for-seafarers.aspx>

Lillie N (2006) A global union for global workers: collective bargaining and regulatory politics in maritime shipping. Routledge, New York

McConnell ML (1985) Darkening confusion mounted upon darkening confusion: the search for the elusive genuine link. J Marit Law Commer 6:365

McConnell ML (1987) Business as usual: an evaluation of the 1986 United Nations Convention on Conditions for Registration of Ships. J Marit Law Commer 18:435

McConnell ML (2009) 'Making labour history' and the Maritime Labour Convention, 2006: implications for international law making (and responses to the dynamics of globalization). In: Chircop A, McDorman TL, Rolston SJ (eds) The Future of Ocean Regime-Building: Essays in Tribute to Douglas M. Johnston. Martinus Nijhoff/Brill, Leiden, pp 349-384

\footnotetext{
${ }^{44}$ See McConnell et al. 2011, supra note 12, at p. 24, footnote 66:

McConnell 1987, 1985. See also, for example, the resurrected call for a definition of the 'genuine link' or even, in the fishing sector, a new convention to 'define' the genuine link in Resolutions 58/240 (at para. 42) and 58/14 adopted by the UN General Assembly at its 58th session. These resolutions invited the IMO and other relevant agencies to study, examine, and clarify the role of the genuine link in relation to the duty of flag States to exercise effective control over ships flying their flag, including fishing vessels. Resolutions 59/24 (para. 41) and 59/25 (para. 30) also requested the Secretary-General to report to the General Assembly at its 61st session on the study undertaken by the IMO in cooperation with other competent international organizations on the role of the genuine link and the potential consequences of non-compliance with duties and obligations of flag States described in relevant international instruments. The IMO reported on 23 June 2006 and the lengthy report comprising reports from the various organization concerned was reported to the General Assembly (Item 69 (a) of the provisional agenda in connection with Oceans and the law of the sea, General Assembly, 61st Session, UN Doc. A61/160, 17 July 2006). Despite some resurgence of interest in the meaning of the genuine link in cases before the International Tribunal on the Law of the Sea, that report commented, inter alia,
}

28. Participants in the meeting took the view that the exclusivity attached by the United Nations Convention on the Law of the Sea to the right of States to fix conditions for the grant of nationality, as reaffirmed by the authoritative interpretations of the International Tribunal for the Law of the Sea in the $M / V$ Saiga (No. 2) and subsequent cases, as well the other agreements referred to in section 2 above, indicated that the questions relating to the precise criteria or conditions adopted by a State with respect to the grant of its nationality to a ship were a matter beyond the purview of the organizations participating in the Meeting. However, participants in the Meeting also considered that issues relating to securing the objective and purpose of the "genuine link" requirement, that is, assuring the ability of the flag State to effectively exercise its jurisdiction over ships flying its flag were matters of central concern to all of the organizations and formed a substantial part of their programmes of regulatory initiatives and technical cooperation activities in the shipping and fishing sectors. 
McConnell ML (2011) The ILO's Maritime Labour Convention, 2006: filling a gap in the law of the sea. MEPIELAN E-Bulletin, April 2011, available at: <http://www.mepielan-ebulletin.gr/>

McConnell ML, Devlin D, Doumbia-Henry C (2011) The Maritime Labour Convention, 2006. A Legal Primer to an Emerging International Regime. Martinus Nijhoff/Brill, Leiden, available at $<$ http:// www.brill.nl/maritime-labour-convention-2006>

Ninth Sitting (2006) "Final record vote on the adoption of the Maritime Labour Convention, 2006," ILC, 94th (Maritime) Session, Geneva, 23 February 2006, ILO Doc. No. PR17, available at < http://www. ilo.org/public/english/standards/relm/ilc/ilc94/pr-17.pdf>

Wu B, Sampson H (2005) Reconsidering the cargo sector's seafarer labor market: a 21st century profile of global seafarers. In: Chircop A, McConnell M (eds) Ocean yearbook, volume 19. University of Chicago Press, Chicago, pp 357-380 